\title{
The politeness of Language; Mata Najwa Show in Trans7 TV
}

\author{
Deni Wahyuni ${ }^{1(*)}$, Syahrul Rahmadhan ${ }^{1}$ \\ ${ }^{1}$ Fakultas Bahasa dan Seni, Universitas Negeri Padang, Indonesia \\ "Corresponding author.Email: deniwahyuni06@student.unp.ac.id_syuhrul_r@unp.ac.id
}

\begin{abstract}
Modesty is something that is considered important by the language community, especially the language community that is in an environment with culture and norms that are still held firmly. In the current era of globalization, with the level of technology and civilization beginning to be modern and advanced, all aspects of life in society are beginning to change. One of them is social values that exist in the community, both in the form of dress behavior, acting and speaking. Everyone has the right to talk about the truth, directly even if they make people's faces threatened, in the form of shame or guilt. The choice of words used in expressing this opinion shows the firmness of the argument. That is what happened in the discussion about the political parties that were appointed in the Mata Najwa event on Trans7. Disagreements and differences of opinion that occur between participants in each communication carried out are loud, offensive, and use harsh words that sound unkind. From the results of the research, it can be concluded that the manifestation of the principle of politeness in the Mata Najwa event on Trans7. consists of a number of maxims consisting of a) maxim of wisdom which is in the form of directive action; b) the maxim of generosity in the form of expressive action; c) the maximal award which is expressive; d) the maxim of simplicity which is expressive; e) maximal agreement which is in the form of assertive action; and f) the maximal conclusions that are tangible actions.
\end{abstract}

Keywords: politeness, language, maxim

\section{INTRODUCTION}

Politeness is considered important by the language community, especially the language community who are in an environment with culture and norms that are still held fast (Nurjamily, 2015). The use of politeness in language to avoid conflicts that will occur if you do not use polite language. According to Mislikhah St (2010), politeness that is used in the community can be seen in everyday relationships. First, politeness of attitude, which is to show the attitude that contains the values of courtesy and daily ethics. Second, politeness that is contextual, that is, which applies in different communities, places and situations. Third, politeness of two poles, that is politeness that occurs because there is a relationship with obligations to one another. Like children to parents, students to teachers and young people to older people. Fourth, politeness in dressing, doing and speaking. In the current era of globalization, with the level of technology and culture that starts modern and advanced, all aspects of life in society begin to change. The relationship between culture and technology has been studied in several studies. Pacey (1985) focuses on cultural views on technical issues in society, such as nuclear weapons, pollution, biological technology. Slack and Wise (2014) investigates technology culture in society and tries to create a new alternative cultural study approach to involve technology culture. Orevbu (1997) approaches the subject in terms of cultural differences in different societies and the development of new technologies in society because these cultural differences consider different countries. Carley (1995) studies communication technology in terms of its influence on cultural issues. Pinchot et al. (2010) work on cellular technology in the perspective of how to change culture.

One of them is the social values that exist in society, both in the form of behavior, dress, act and talk. Everyone has the right to talk about the truth, directly though it makes people's faces threatened, in the form of shame or guilt. The choice of words used in expressing this opinion shows the firmness of the argument. That is what happened in the discussion about the cases raised in the Mata Najwa program. Disagreement and differences of opinion that occur between participants in any communication carried out loud, offensive, and use harsh words so that it 
sounds impolite. That is what later became the background of this research.

In politeness in language, there are several maxims expressed by Leech (1993) dividing politeness theory into six maxims, namely: (1) the maxim of wisdom outlines that each speech participant must minimize the losses of others, or maximize the benefits for others, (2) the maxim acceptance requires the speaker to minimize his own gain and maximize his own loss, (3) the maxim of mercy requires the speaker to minimize criticism of others, but must maximize praise to others, (4) the maxim of humility requires the speaker to minimize praise to himself, but must denounce themselves as much as possible, (5) the maxim of compatibility requires one to maximize agreement with others and minimize disagreement with others and (6) the maxim of sympathy requires speakers and speech partners to maximize sympathy and minimize antipathy between themselves . As a conclusion to the theory of politeness from Leech (Chaer, 2010: 61-67) summarizes it as follows. a) The maxim of wisdom, the maxim of acceptance, the maxim of generosity and the maxim of humility are those that relate to the advantages or disadvantages of oneself and others. b) The maxim of suitability and the maxim of concurrency are those that relate to bad or good judgment of themselves or others.

The problem in this study can be formulated as follows. (1) The types of maxims contained in the Najwa Sihab dialogue with the resource person, (2) What is the speaker strategy during the interactive dialogue. The purpose of this study includes three things as follows; (1) Describe the types of maxims that are contained in the Najwa Sihab dialogue with the resource persons; (2) Describe the speaker's strategy during an interactive dialogue. Several studies examining the politeness of language have been widely studied before. First, Sarangih (2013) he examined anthropolinguistics as an interdisciplinary field that studies language as a cultural resource and speaks as a cultural practice using a pragmatic approach. The results of the analysis show that the politeness of the Pasisi Barus language community in family and environmental interactions is manifested in five forms of speech acts, namely: (1) refusing. (2) asking, (3) commanding. (4) prohibits, and (5) offers. Strategies for realizing the politeness of the language used by Pasisi Barus are: (1) giving reasons, (2) being pessimistic, (3) indirect, (4) apologizing. (5) thanking, (6) delaying, (7) using hedging, and (8) minimizing coercion. Based on this strategy, there are ten patterns used by Pasisi Barus in expressing politeness in language. The politeness of language reflects two policies, namely: (1) avoiding conflict and (2) being tolerated. Local wisdom is reflected in the politeness of the language of the Barus Basisi Society taught by the oldest to the youngest by applying language politeness in everyday communication.

Secondly, Noor and Prayitno (2015) His research described patterns of politeness and forms of positive politeness shifting that were used among class IX students of MTs N 1 Surakarta. In addition, this study also aims to find out the factors that influence the emergence of a positive politeness shift among IX grade students of MTs N 1 Surakarta.

Third, Febriasari and Wijayanti (2018) the results of their research concluded that in the video recordings it was found that students who obeyed and violated the principle of politeness in language. Compliance with the principle of politeness in language consisted of maximizing wisdom, generosity, appreciation, simplicity, consensus, and sympathy. The videotape also found speeches of students who violated the principle of politeness in language which consisted of violations of the maxim of wisdom, generosity, appreciation, simplicity, consensus, and sympathy. When compared, in the learning process there are still many students who use impolite language than students who use polite language towards teachers or other students. This happens because they assume learning will feel more relaxed when using informal language. Kemudian, Gustiva (2016) tujuan penelitiannya adalah mendeskripsikan penggunaan kesantunan bahasa dalam proses komunikasi di media massa televisi. Proses komunikasi bukan hanya mempertimbangkan bahasa sesuai aturan tata bahasa saja, tetapi juga harus melihat kepatutan dan kesantunan dalam penggunaannya. Selanjutnya, Purwati Ni Made Anggun (2017) Penelitiannya bertujuan untuk mendeskripsikan (1) pemenuhan prinsip kesantunan pada Talkshow Rumpi (No Secret) di Trans TV; (2) pelanggaran prinsip kesantunan pada Talkshow Rumpi (No Secret) di Trans TV; dan (3) dampak psikologis pemenuhan dan pelanggaran prinsip kesantunan oleh penutur terhadap mitra tutur pada Talkshow Rumpi (No Secret) di Trans TV. To achieve this goal, researchers used a qualitative descriptive design with the speech of the presenter and guest stars as research objects. The subject of this study was the host and guest star Talkshow Rumpi (No Secret), which was broadcast on Trans TV. The results of his research include (1) compliance with the principle of politeness by the host and guest stars on the Talk Show (No Secret) on Trans TV; (2) violation of politeness principle by the presenter and guest stars in the No Secret Talkshow on Trans TV, and (3) the psychological impact of compliance and violation of politeness principle by the speaker for the speech partners on the Talkshow Rumpi (No Secret) on Trans TV

Furthermore, Aminah (2017) examines politeness in Arabic sentences especially about the politeness strategies used in the Kaukab Amu> n. By using the concept of courtesy Brown and Levinson, it was concluded that for communication to be smooth and harmonious, the speaker and listener use positive politeness strategies and negativity. A positive politeness strategy is used to keep the distance between the speaker and the listener in the form of avoiding conflict, involving the opponent in certain activities or speakers, promising, giving praise, expressing jokes, giving attention and sympathy, using certain identity identifiers, asking for approval, and showing optimism. Negative politeness strategy is done by using indirect sentences, reducing the strength or threat to the other person, by using an expression of apology, and paying homage to the listener. In the inter-character dialogue in the Kaukab Amunn novel, it is found a form of 
facing threats, both positive and negative face threats and the characters use the face saving act strategy.

\section{METHOD}

This research is a qualitative descriptive study. According to Arikunto (200: 10) "Research conducted by explaining or drawing past and present variables (currently occurring), descriptive research (todescribe to describe or expose)". Qualitative research according to Sugiono (2012: 15) "Qualitative research is a research method based on postpositivism, used to select natural objects as key instruments for sampling data sources conducted purposively and snowbaally. It is said to be descriptive because this research seeks to describe the facts of politeness in language on the TV show Mata Najwa. Called qualitative because the data obtained is not in the form of numbers, but the form of words. The research was conducted by observing the speech of Najwa Sihab with the speakers. This research focused on the Najwa Sihab dialogue with the speakers.

Data collection procedures in this study are by observing the speech of Najwa Sihab with the speakers. Data were analyzed referring to the speech of Najwa Sihab with the speakers. The analysis of this research is a qualitative descriptive analysis technique. Qualitative descriptive analysis technique is a technique of analyzing data by interpreting data obtained with words. To examine the validity of data regarding the realization of politeness in language, this study uses four techniques. The four techniques are 1) perseverance of observation, 2) triangulation, 3) referential adequacy, and 4) peer examination through discussion.

\section{RESULTS AND DISCUSSION}

Implementation of the Principle of Politeness

The Maxims of Wisdom or Wisdom (Taxt Maxim)

The implementation of this wisdom maxim is seen in the speech contained in the Mata Najwa program on Trans7 below.

Najwa Sihab: To be clear, Kang Dedi used to be Prabowo's success team Five years ago

Dedi Maulana: right

Najwa Sihab: correct, so that tonight's position is clear. Past and present.

Speech context: (Narrated by Najwa Sihab to Narasu, he said, when discussing the position of Dedi Maulana, formerly the Pak Prabowodan success team, now Jokowi's success team. Each speech participant must minimize the losses of others, or maximize profits for others. above illustrated that Najwa Sihab minimized the loss of his interlocutor Dedi Maulana by asking the question "to be clear, in the past Kang Dedi was Prabowo's success team five years ago" and followed by affirming the question given "correct, so that the position is clear tonight. now."

Generosity Maxim (Generosity Maxim)

The following is a description of the implementation of this maxim in the Mata Najwa event on Trans7

Najwa Sihab: what is the reason you turn your heart?
Hutinanean Federation: Thank you, Ms. Nana, this is indeed politics and dynamics. I used to know Mr. Jokowi ever since he ...

Speech context: (Spoken by Najwa Sihab to the Hutahaean Fedinan about the reasons the Hutinanean Fedinan turned politics)

With the maxim of generosity, the participants are expected to be able to respect others. Respect for others will occur if people can reduce profits for themselves and maximize profits for other parties.

The speech above uses the maxim of generosity, namely by reducing self-benefit and adding to the benefits of others, this is seen in the following sentence, "thank you, Ms. Nana this is indeed the politics" Fedinan Hutahaean uses the above sentence to reduce his own profit by adding his opinion about the discussion with explain about the journey of political dynamics that he experienced.

Maximum Award (Aprobation Maxim)

Najwa Sihab: My question is specific so what made you move to other hearts?

Fedinan Hutahaean: In the past, I knew that Pak Jokowi understood Bung Karno's teachings because every time we discussed, we always talked about Tri Sakti and Tri Sakti, I am an admirer of Tri Sakti ...

Speech context: (Spoken by Fedinan Hutahaean a jokowi supporter when asked by Najwa Sihab about the reasons for moving hearts). The above dialogue uses expressive utterances in the form of Fedinan Hutahaean praise to Jokowi, the Indonesian president. In the maxim of appreciation explained that someone will be considered polite if in speaking always try to give appreciation to other parties. With this maxim, it is hoped that the participants of the speech will not mock one another, berate each other, or demean each other. Speech participants who often mock other speech participants in speaking activities will be said to be rude. It is said so because the act of mocking is an act of disrespect for others.

Maksim Kesederhanaan (Modesty Maxim)

The following are the utterances that use the maxim of humility in the Mata Najwa event on Trans7

Fitra: Is it because you don't enter the cabinet that you are disappointed?

Hutinanean Fedinan: oh, no because at the time of the preparation of the cabinet I was the one who protested the most Jokowi.

The utterances expressed by Fedinan Hutahaean clearly use the maxim of simplicity. In the maxim of simplicity, speech participants are expected to be humble by reducing praise to themselves. People will be said to be arrogant and proud if in speaking activities always praise and favor themselves. The maxim appeared in the sentence "no because at the time of the preparation of the cabinet I was the loudest protesting against Jokowi."

Maximum Agreement (Maxim Agreement)

The following is a snippet of utterances that contained the maxim of agreement

Najwa sihab: So that is the reason for Pak Ferdinand's version? 
Fedinan Hutahaean: yes, that is the reason for my version.

The utterance that occurred in the dialogue between Najwa sihab and Fedinan Hutahaean showed an agreement or compatibility with the opinions expressed by Najwa sihab, this is the maximal form of compatibility between Najwa sihab and Fedinan Hutahaean. understanding and agreement appear in the speech uttered by Fedinan Hutahaean. Speech that shows this agreement appears in the words, "yes, that is the reason for my version!"

6. Maximum Conclusion (Sympath Maxim)

Najwa sihab: The reason you supported JOkowi, until you were accused of being a traitor by your own family?

Fitra: I will explain, I have never entered a political party except PDIP, so I have not jumped from any political party.

The dialogue that took place between Najwa sihab and fittr seemed to use the maxim of the sympathies expressed by Fitra to Najwa sihab. in the maxim of sympathy, it is expected that the speech participants can maximize the attitude of sympathy between one party with another party. If the interlocutor gets success or happiness, the speaker is obliged to give his congratulations. If the interlocutor gets into trouble, or the speaker is worthy of grief, or expresses his condolences as a speaker of sympathy.

\section{CONCLUSION}

From the results of the discussion, it can be concluded as follows the form of the implementation of politeness principles in the Mata Najwa event in Trans7 consisting of a number of maxims consisting of covering a) maxim of wisdom in the form of directive action; b) maxim of generosity in the form of expressive acts; c) maxim of appreciation in the form of expressive acts; d) maxim of simplicity in the form of expressive acts; e) Maximum agreement in the form of assertive acts; and f) maxim of conclusions in the form of assertive acts.

\section{REFERENCES}

[1] Arikunto, Suharsimi. (2006) Research Process Something Practical Approach. Jakarta: Rineka Cipta.

[2] Carley K. (1995). Communication technologies and their effects on cultural homogeneity, consensus, and the diffusion of new ideas. Sociological Perspectives, 38 (4): 547-571.

[3] Chaer, Abdul (2010). Language Politeness. Jakarta: Rineka Cipta. Dajjasudarma,

[4] Febriasari, Diani (2018). Politeness in language in the learning process in elementary schools. Credo Journal. Vol. 2 No. 1, p. 140-156

[5] Gustiva Widya, (2016), Realization of Politeness in the "Mata Najwa" Talk Show. Language Check. Vol 2 No. 2, pp. 230-236

[6] Kumala Sari Mei Anjar, (2018), Pragmatic Study of Arabic Languages in the Kaukab Amun Novel by Sally Magdi. Journal of Indonesian Language and Literature Education. Vol. 3 No1, p. 34-43
[7] Leech, Geoffrey. (1993). Pragmatic Principles. Jakarta: University of Indonesia Publisher (UIPress).

[8] Mislikhah, St. (2014). Courage in Language. Journal Arraniry. No.2 Vol. 1, p. 8-29

[9] Purwati Ni Made Anggun. (2017). The Principle of Politeness in the Rumpi (No Secret) Talk Show on Trans Tv. Journal of Ganesha University of Education, Department of Language and Literature Education in Indonesia. Vol 6 No. 1 thing. 1-10

[10] Noor Khilyatin Ulin, Prayitno, Harum joko. (2018) Shifting the Positive Politeness of Class IX Students in MTs N 1. Surakarta with Javanese Cultural Background. Journal of the University of Muhammadiyah Surakarta. Vol.1 No.1, p. 17-24

[11] Nurjamily, Wa Ode. (2015). Indonesian politeness in family circle (sociopragmatic study). Journal of Humanika No.15 Vol.3, p. 35-42.

[12] Orevbu AO. (1997). Culture and Technology. New York: UNESCO Report No: CLT / DEC / Pro 1997.

[13] Pacey A. (1985). The Culture of Technology. Boston: The MIT Press.

[14] Pinchot JL, Paullet KL, Rota DR 2010. How Mobile Technology is Changing Our Culture. Conference on Information Systems Applied Research 2010 CONISAR Proceedings, Nashville, Tennessee, USA.

[15] Sugiyono 2012. Educational research methods approaches quantitative, qualitative, and R \& D. Bandung: Alfabeta.

[16] Saragih Yenny Puspita. (2013), Local Wisdom of Politeness in Language in the Community of Pasisi Barus. USU Journal. ISSN 1693-1660. No., p. 139152

[17] Slack JD, Wise JM (2014). Culture and Technology: A Primer. New York: Peter Lang Publishing Inc.

[18] Yule, George. (2006) Pragmatics. Banjarmasin: Unlam. 